\title{
FORMAÇÃO E DESENVOLVIMENTO DA NAÇÃO E DO PENSAMENTO CIENTÍFICO E SOCIAL NO BRASIL E O PAPEL DA EDUCAÇÃO
}

\author{
Marival Coan ${ }^{1}$ \\ PPGE/UFSC/IF-SC
}

\section{RESUMO}

O presente ensaio tem por objetivo analisar aspectos da formação da nação brasileira, bem como, aspectos relativos à formação e desenvolvimento do pensamento científico e social no Brasil e o papel atribuído à educação nesse processo. Procura compreender a educação como projeto em permanente disputa entre os diversos atores sociais e reivindicada como fundamental para o progresso da nação, sem, contudo, oportunizar os recursos devidos para ofertá-la ao conjunto da população. Também busca compreender a educação como atividade mediadora no seio da prática social global. A constituição e o desenvolvimento do pensamento científico e social são entendidos em sua estreita relação que têm com o desenvolvimento socioeconômico. O Brasil tem, em sua formação inicial, a hegemonia de uma elite escravocrata que se mantém à custa da exploração do trabalho escravo, seguida de uma elite agroindustrial, depois industrial, que se constituiu, se manteve e se mantém por meio da exploração dos trabalhadores assalariados. A nação brasileira carrega em sua história a lógica da exclusão, do elitismo, do pouco caso com as questões sociais, dentre elas, a educação. Contudo, as condições sociais e culturais, que servem de suporte e oferecem meios favoráveis de desenvolvimento ao saber racional, começam a constituir-se em ritmo regular, na sociedade brasileira, a partir do início do século XIX, estendendo-se lentamente até os dias atuais.

Palavras chave: formação e historicidade da nação brasileira e do pensamento científico e social, educação; questões sociais.

\section{FORMATION AND DEVELOPMENT OF THE NATION AND THE SCIENTIFIC AND SOCIAL THOUGHT IN BRAZIL AND THE ROLE OF EDUCATION}

\begin{abstract}
This essay aims to examine aspects of the Brazilian nation formation as well as aspects of training and development of scientific and social thought in Brazil and the role given to education in this process. It seeks to understand education as a project in permanent dispute among the various social actors and claimed as essential for the progress of the nation, without, however, making appropriate resources available and offering it to the whole population. It also seeks to understand education as a mediating activity within the global social practice. The establishment and development of scientific and social thought is understood in its close relationship with the socio-economic development. Brazil has in its initial formation the hegemony of a slaveholding elite that remains at the expense of slave labor exploitation, then by an agro-industrial elite, which became industrial later. This industrial elite was formed, maintained and it still remains on the exploitation of employees. The Brazilian nation carries in its history the logic of exclusion, elitism and neglect of social issues, among them education. However, the social and cultural conditions, which support and provide the favorable means to the development of rational knowledge, start to act as a regular rhythm in Brazilian society from the early nineteenth century, in a slow process that continues until today.

Keywords: formation and history of the Brazilian nation and scientific thought and social; education; social questions social
\end{abstract}




\section{INTRODUÇÃO}

Este texto delineia, em contornos gerais, o desenvolvimento do pensamento científico e social no Brasil, suas vinculações ao pensamento externo, sobremaneira ao europeu; e, também, o papel atribuído e desempenhado pela educação, de modo especial, pela educação formal escolar. Procurar-se-á mostrar que a formação e o desenvolvimento do pensamento científico e social no Brasil se encontram intrinsecamente relacionados ao grau de desenvolvimento econômico, político e social da nação brasileira.

A delimitação histórica do presente estudo configura-se a partir das primeiras iniciativas educativas realizadas no Brasil e patrocinadas pelos jesuítas, desdobrando-se até os dias atuais. Dar-se-á ênfase ao contexto da independência - momento em que se dá a formação do Estado nacional imperial brasileiro - à luta abolicionista, e ao processo que culminou com a proclamação da República no final do século XIX. Nesse trabalho de análise da constituição econômica, política e sociocultural da sociedade brasileira, buscarse-á perceber qual o papel desempenhado pela educação, enquanto proposta de caminho para a civilização, e as ações políticas, de fato, implementadas.

Não se trata de uma historiografia; nesse caso, a condução histórica serve como balizamento para a compreensão do fenômeno da formação da nação e do pensamento científico e social, bem como, do papel desempenhado pela educação formal nesse processo. Nesse sentido, a apresentação dos autores e textos que refletem tal cronologia histórica foi feita pelo fato de permitirem analisar a temática com uma perspectiva crítica, ou, pelo menos, oferecem elementos para tal.

\section{FORMAÇÃO DA NAÇÃO E DO PENSAMENTO CIENTÍFICO E SOCIAL NO BRASIL COLONIAL}

A sociedade brasileira, nos seus primórdios e em seus múltiplos aspectos, esteve sempre submissa às ideias europeias. O Brasil colonial era dependente da Europa, particularmente de Portugal; tratava-se, por conseguinte, de relações coloniais. O caldo cultural colonial era produzido a partir das ideias trazidas pelas ordens religiosas, particularmente a dos jesuítas, que determinavam os rumos da educação, das artes e da religiosidade desenvolvidas no Brasil.

O modelo de educação dos jesuítas, cujas ideias eram contrarreformistas, desenvolvia-se a partir da Ratio Estudiorun ${ }^{2}$, que primava por um currículo centrado na teologia cristã, na filosofia, nas artes sacras e nas línguas. Pode-se dizer que a presença dos jesuítas, bem como de outras ordens religiosas, significou o aniquilamento da cultura nativa e a implantação de um modus vivendi europeu. Nesse processo de colonização, a religião desempenhou papel importantíssimo. A evangelização, portanto, consistia em dominação. Na condição de colônia, os interesses do Brasil estavam subsumidos aos interesses de Portugal e da Igreja - neste texto, entenda-se igreja católica - sob todos os aspectos.

Nesse sentido, as condições para a elaboração do pensamento científico ficaram comprometidas. Florestan Fernandes $(1980$, p.15) observa que "as atividades inerentes à pesquisa fundamental e à elaboração ou à transmissão de conhecimentos científicos exigem certas condições histórico-culturais e sociais". Ainda mais que, para o autor, o saber racional desabrocha em sociedades em que indivíduos se dedicam à atividade criadora de explicação do cosmos. 
Quando atividades dessa ordem: a) se associam às concepções secularizadas da existência, da natureza humana e do funcionamento das instituições. b) $\mathrm{O}$ acesso aos papéis de produção intelectual se torna aberto, deixando de ser prerrogativa de determinadas castas, estamentos ou círculos sociais. c) Estilos divergentes de pensamento passam a disputar o reconhecimento público de sua legitimidade ou vaidade - o saber racional assume naturalmente a forma de saber positivo ou científico. (FERNANDES, p. 15-16).

Ora, essas condições acima apontadas por Fernandes emergiram muito tempo depois na sociedade brasileira. No período colonial - que se estende do século XVI ao começo do século XVIII - os papéis intelectuais, ligados ao saber racional, foram quase todos monopolizados pelo clero. O clero se incumbiu tanto da transmissão e da propagação da fé religiosa, quanto da educação das novas gerações e da orientação espiritual dos círculos dominantes.

Coube também à Igreja, exercer uma influência contínua e profunda na construção da intelectualidade e concepções de mundo. Essa influência, porém, não era de caráter inovador, visto que o clero brasileiro, inserido numa sociedade colonial escravista, era de caráter conservador acentuado, com raras exceções. Além do mais, "a Igreja fazia parte e era solidária, material e moralmente, com os empreendimentos colonizadores do Reino" (FERNANDES, p. 17). Daí resulta que "o clero deixou de incutir aos papéis intelectuais, inerentes à atividade sacerdotal, qualquer dinamismo interno, intelectualmente criador" (FERNANDES, p. 17), mesmo tendo contribuído para o transplante de um dado saber que não encontrou condições culturais propícias na ordem existente.

Com o fim do período predominantemente açucareiro e a introdução da mineração, no século XVIII, ocorreram algumas transformações, como, por exemplo, o crescimento urbano, principalmente em Minas Gerais; a expansão de atividades ligadas ao comércio e à exportação; surgiram novas ocupações como comerciantes, artífices, criadores de animais, funcionários da administração que controlavam a extração de minérios e sua exportação.

Pela primeira vez, a população livre era mais numerosa que a escrava. Costa (2000, p. 171) destaca a importância dessa nova fase histórica. "Essa camada intermediária livre e sem propriedades, que precede o surgimento da burguesia propriamente dita, torna-se consumidora da erudição da cultura europeia, em especial da francesa, numa tentativa de se distinguir tanto do escravo inculto como da elite colonial conservadora". Contudo, as condições sociais e culturais que servem de suporte e oferecem meios favoráveis de desenvolvimento ao saber racional começam a constituir-se com ritmo regular, na sociedade brasileira, somente a partir do início do século XIX, como se verá a seguir, uma vez que foi nessa época que surgiram as primeiras pressões no sentido de se formar um setor da população responsável pelo exercício de tarefas administrativas e políticas.

Mesmo assim, os interesses da aristocracia brasileira em formar bacharéis para lhes servir; a existência de uma sociedade estratificada com baixíssima mobilidade social e a prática da escravidão que desvalorizava as práticas manuais como servis tornaram insuficientes as condições para a formação do saber racional autônomo, capaz de evoluir como uma esfera especializada de atividades culturais. Eis a razão principal de se recorrer aos centros externos para solucionar os problemas decorrentes da trama histórica interna.

\section{INDEPENDÊNCIA E FORMAÇÃO DO ESTADO NACIONAL BRASILEIRO E O PAPEL DA EDUCAÇÃO}


No período de formação do Estado nacional imperial brasileiro - século XVIII percebe-se que a educação não recebeu a devida atenção, por parte dos constituintes. A construção do projeto de Brasil, como nação, está alicerçada na ordem escravocrata, uma vez que a elite brasileira optou pela manutenção dessa forma de trabalho e, administrativamente, prevaleceu a política de centralização ${ }^{3}$. No período de declínio do império, manifestam-se perceptíveis as articulações da elite escravocrata para fazer a transição do trabalho escravo para o assalariado.

Nesse período, conforme Bethel (2001), surge - paralelo à ideia de nação - o conceito de povo, mas não com o sentido atual, entendido como cidadania plena. Pode-se afirmar que a vida no Brasil, nesse momento, é mais que a simples relação social dominante entre senhores e escravos. Já existem uma vida social, uma tessitura social mais complexa. Esse período, também, serve de contexto para o romantismo, com destaque para as produções de José de Alencar e sua ideia de índio romantizado.

Bethel (2001), assim como Pimenta (2002), salienta que a conjuntura internacional do período faz com que Portugal tenha muito mais uma dependência econômica de suas colônias com destaque para o Brasil, que o seu contrário, bem como, faz perceber os reais interesses da Inglaterra em acabar com o tráfico de negros. Está claro o interesse político e econômico da Inglaterra do que propriamente a luta por dignidade da raça negra. A Inglaterra já havia feito a revolução industrial e abolido o trabalho escravo. A Europa, como um todo, vive nesse momento a era pós-revolução burguesa, por isso, as razões de serem contra o trabalho escravo. O escravo não condiz com o mundo da modernidade.

A inserção do Brasil, no entanto, no processo de revolução clássica europeia é periférica, uma vez que, de fato, pouco se fez internamente pela independência do país; a própria vinda da família real foi muito bem pensada e pode ser vista muito mais como uma articulação das elites brasileira e portuguesa do que como um processo emancipatório. $\mathrm{O}$ Brasil apresenta-se aos olhos europeus como um país rico em recursos naturais dos mais variados e, por consequência, passa a ser visto pelo colonizador como fonte de riquezas. Internamente, a elite tem acesso ao que há de melhor no mundo de então. Seus filhos, por exemplo, vão estudar na Europa e respiram tais ares. Com certeza, a aristocracia brasileira sabia o que estava fazendo e o que queria. A nação e a ideia de povo estão nascendo nesse contexto da independência; contudo, o escravo não é tratado como gente, pois é considerado "peça", "coisa", "propriedade". De forma semelhante, os índios e demais pobres não são interlocutores da história - o Brasil continua escravocrata e monárquico.

Retomando o contexto da independência e a temática da educação, Chizzotti (1996) salienta que a Constituinte de 1823 sintetiza as relações de forças sociais e políticas que deram as condições à independência. Os movimentos de resistência e os altos custos para a manutenção do regime geravam um clima de instabilidade. A isso se somava a penúria das províncias, que eram extorquidas pelas obrigações tributárias, a miséria dos agricultores, a indigência dos artesãos e senhores de pequenos ofícios, todos alijados da proteção real. Viviam na pobreza de todas as formas, tanto na cidade como no campo. A elite que formava a Assembleia Constituinte representava seus interesses, e não os desse povo sofrido e marginalizado.

A educação foi tema da Assembleia Constituinte de 1823, e D. Pedro I, em seu discurso, fala em instrução pública. Qual seria o sentido de colocar a educação pública na constituição de 1823? Certamente para preparar a classe dirigente e substituir, com o tempo, a mão-de-obra escrava e implantar as primeiras indústrias. Nesse contexto, a educação no Brasil era ofertada somente de modo particular, nas casas. Os professores visitavam as pessoas em suas casas para ensinar as primeiras letras. Posteriormente, como já aqui mencionado, a elite ia à Europa para estudar. Contudo, essa mesma elite via como 
problema tal fato. Por outro lado, o Estado precisava de gente formada, de "bacharéis", ou seja: a elite precisava da escola. Entretanto, a Assembleia Constituinte não tinha um projeto político de ampliação da educação como direito de todos. A educação, assim como outros direitos sociais, não é pensada pelos pobres e para os pobres.

A ideia de escola pública entra no Brasil mediada pelo projeto da elite monárquica e pelos liberais, cuja preocupação central não é a instrução em seu sentido lato, e sim a moralização. Tanto é verdade que a Assembleia Constituinte chegou até a fazer um concurso para quem trouxesse de modo sistemático e uniforme, todos os conhecimentos necessários à educação da mocidade. Tal tratado deveria conter a educação física, moral e intelectual da mocidade. Afora o plano da criação da universidade brasileira, aprovado pela Assembleia e sancionado pelo imperador, Rodrigues (1974) salienta que a Constituinte foi de resto muito tímida no que tange à educação, e as discussões, muito pouco trouxeram de prático.

Após a Constituinte, a educação passou a ser aplicada em outro local que não as casas das pessoas. Determinou-se um ambiente, um prédio, onde as crianças deveriam ir, e coube à Igreja desempenhar o papel de convencer as famílias a mandarem seus filhos para a escola. Do ponto de vista político, a consolidação de uma monarquia constitucional com suas contradições foi a solução política apresentada para o Brasil independente e o período da regência $(1832$ - 1850) se apresenta como um período tenso.

Os liberais, por meio das revoltas, organizam o poder político e a Lei de 1834 provoca reformas na maneira de administrar o império, patrocinando um novo ordenamento jurídico e político do país. Os movimentos de insurreição demonstram certa fragilidade e são tratados com violência - o que mostra que o Brasil não era um "país da calmaria".

No que tange à construção do projeto de nação brasileira, pode-se afirmar que o mesmo é pensado a partir da mentalidade da classe dominante. Von Martius (1845), por exemplo, escreve em seu texto de 1845, que a história do Brasil deve ser contada a partir dos portugueses; do sangue poderoso dos brancos. Os portugueses aparecem como homens de negócio, viajantes. A base é europeia, católica, elitista, monarquista e escravista.

Ou seja, o conceito de nação como totalidade não é considerado. Robert Rowland (2003), por exemplo, evidencia como as diferentes interpretações do "povo" e do "estrangeiro" - no caso, do "português" - foram sendo articuladas ao longo do século XIX de modo que constituíssem o ponto de partida para a elaboração acerca da identidade nacional. Em todo o continente americano, os processos que conduziram a independência estavam marcados por tentativas de construção de identidades nacionais. Tais identidades eram construídas pelas elites dominantes a partir do mundo europeu, e não a partir das tradições dos povos indígenas. A elite imperial brasileira procurou cultivar a imagem de uma civilização europeia transplantada para a América tropical.

$\mathrm{O}$ autor também destaca que o antilusitanismo existente no Brasil provém de um conjunto de atitudes da corte, principalmente no favorecimento de alguns em detrimento dos demais. Foi entre os setores menos privilegiados da população livre, que subsistia e crescia à margem do processo produtivo, que tal fenômeno tornou-se mais agudo.

Indubitavelmente, a continuação da escravidão e a existência da monarquia centralizadora impossibilitavam a noção de povo, de nação. Foi somente com o regresso da família real e com a vitória das forças centralizadoras que se criaram as condições para a emergência de um discurso propriamente nacional. Mesmo existindo um discurso relativo ao "povo", deve-se destacar que se tratava apenas de um discurso, uma vez que este esteve ausente, à espera de ser transformado de matéria-prima em sujeito. Além dos milhões de índios e escravos, vegetavam outros milhões de pessoas à espera de um futuro melhor. 
E mesmo após a abolição, a escravidão continuou a projetar a sua sombra sobre o corpo social brasileiro, e a construção do país ainda dependia da importação de trabalhadores estrangeiros. Esses, para despeito dos trabalhadores brasileiros que até então tinham sido mantidos à margem do processo produtivo, passaram a ser considerados como modelo do trabalho assalariado e instrumento de modernidade. No desprezo a que foi posto o trabalhador brasileiro, resume-se a amarga e complexa herança da escravidão. Por essa razão, Oliveira (2003) sustenta a tese de que o suporte da tangibilidade da nação estava relacionado à escravidão e sua superação.

No que se refere aos aspectos políticos, o Brasil mantém, nesse período, o poder político centralizado no poder moderador e no conselho de Estado; e essa nação, representada pelos grupos dirigentes e proprietários enriquecidos, supera a condição de colônia, porém, não abre mão da escravidão como relação predominante de trabalho.

Para abafar as lutas políticas da época, Carvalho (1996) destaca a criação do Conselho de Estado. Tal Conselho era uma forma de "cérebro" da monarquia, e seus componentes, que deviam ter um perfil europeu, eram escolhidos a dedo pelo imperador. Os conselheiros, por fazerem parte da elite política e social, estavam distantes dos ideais populares; logo, o Brasil que representavam não era o Brasil da grande massa do povo.

Mesmo manifestando posições antiescravistas, a análise das atas revela que os debates acerca da escravidão e sua abolição eram polêmicos dentro do Conselho, não havendo consenso, pois a base da riqueza nacional e das rendas do Estado estava relacionada à agricultura, e a agricultura, associada ao trabalho escravo. Se o modelo do Conselho era o do mundo civilizado da Europa e dos Estados Unidos, pode-se dizer que ele muito pouco fez para que o Brasil caminhasse nessa direção.

A realidade contraditória do Brasil desse período, no entanto, não é tema frequente e preocupação precípua das várias representações. Schiavinatto (2003) destaca que o Brasil, sob o olhar dos relatos dos viajantes, é um país romantizado no qual as contradições desaparecem. Os relatos giram em torno dos aspectos físicos e geográficos, com ênfase às belezas e recursos naturais, bem como, da formação heterogênea do Brasil com destaque para as maneiras típicas de ser do índio, do negro e demais habitantes do país.

\section{LUTAS PARA SUPERAR A (DES)ORDEM ESCRAVOCRATA E POR EDUCAÇÃO, QUE EDUCAÇÃO?}

A escravidão e formas de superá-la são parte constituinte da história e formação da nação brasileira, conforme anteriormente sinalizado. Malheiro (1867) apresenta alguns pareceres nessa perspectiva, ou seja, o trabalho dos escravos deve ser substituído pelo trabalho livre no Brasil, talvez, nem tanto pela luta em defesa da dignidade do negro, mas como forma de suprir o déficit de escravos que começa a faltar em consequência das dificuldades do tráfico. Além disso, poucos países do mundo ainda adotam tal forma de trabalho e, na forma de trabalho livre, há poucas reclamações dos trabalhadores. Logo, o setor agrícola, predominante à época, deveria buscar outras formas de trabalho além do emprego do escravo, como, por exemplo, parcerias, pagamento de salários e outros.

O trabalhador livre é guiado pelo amor à propriedade; tem estímulo ao trabalho, enquanto no regime escravocrata, tudo isso morre, e o escravo só tem medo do castigo; portanto, deve-se buscar meios para realizar a abolição lenta e gradativa ${ }^{4}$.

Outros pareceres também apontavam para a extinção progressiva da escravidão no Brasil, inclusive, com a proibição a todos os estrangeiros de adquirirem escravos; liberdade aos que nascessem do ventre escravo a partir de certa data, e quando completassem os 18 anos. A luta pela abolição parece estar consolidada; no entanto, trata-se de um processo moroso. A forma lenta e gradual serve aos interesses dos senhores e, no momento em que 
o Estado foi chamado a resolver o problema da escravidão, transferiu para outras esferas, inclusive instituições filantrópicas, conforme Fonseca (2002).

Ainda para esse autor, a educação, nesse contexto, é utilizada como mecanismo de controle; como um instrumento político que serve para a manutenção da ordem estabelecida. Ao mesmo tempo em que, pela primeira vez, o Brasil tem um documento oficial em que a educação voltada para escravos e libertos aparece de forma explícita, deve-se estar atento que se trata de um projeto pensado pela elite branca para os negros, no qual se via a educação como estratégia disciplinadora e racionalizadora de espaço social.

O autor também salienta que a Lei do Ventre Livre (Lei de $n^{\circ} 2040$ de 1871) foi uma forma que a classe dominante encontrou para fazer frente às pressões políticas da época, visto que se trata muito mais de um arranjo parlamentar para defender os interesses dos senhores de escravos do que de um veículo de emancipação do negro. Esse arraigado apego da aristocracia brasileira à expropriação do trabalho alheio, principalmente do escravo, é um dos motivos que permitem a Fragoso e Florentino (2001) falarem do arcaísmo como projeto, enfatizando que o projeto dos portugueses é arcaico, aristocrático, apegado à tradição, ao catolicismo, à escravidão em relação a outros projetos como, por exemplo, o dos ingleses, que no período já viviam os ares da revolução do capitalismo, do trabalho assalariado.

A análise objetiva da realidade mostra que, de fato, poucos se opunham à escravidão no Brasil, e a classe dominante estava convencida da necessidade de mantê-la. Quando forçada a acabar com o tráfico, deu um "jeitinho" de contrabandear escravos, e os abolicionistas brancos ou negros foram ocasionalmente atacados por escravocratas irados. A escravidão é cruel por si só, em qualquer lugar do mundo, como atesta Viotti (1998). A autora também considera mito pensar que a escravidão no Brasil foi mais branda que nos Estados Unidos, por exemplo. A escravidão no Brasil foi severa, como é próprio dessa forma de sociedade.

O Brasil continuava à margem da revolução industrial que ocorria na Europa e, somente, quando a classe dominante escravocrata viu que não daria mais para manter a escravidão, tratou de se preparar para o inevitável. A saída foi a imigração, iniciada em 1850. Nesse sentido, os fazendeiros do setor cafeeiro tomaram as primeiras iniciativas e quando estas falhavam, os fazendeiros praticavam o tráfico interno de escravos. A luta pela manutenção da escravidão continuou e, somente, em 1880, a maioria estava convencida de que a escravidão era causa perdida. Quando, enfim, a abolição tornou-se objetivada, Viotti (1998) destaca que a mesma, de fato, libertou os brancos do fardo da escravidão e abandonou os negros à sua própria sorte.

Retomando os aspectos relacionados à educação do período, além dos já evidenciados, do ponto de vista do marco regulatório, constata-se que a mesma pouco avançou no período imperial. Na constituição de 1823, os artigos referentes à instrução pública não foram apreciados e a educação mereceu apenas três artigos. Sucupira (1996) enfatiza que a Constituinte não foi fecunda em termos de educação, uma vez que não traçou diretrizes para a educação nacional.

No período entre 1824 - 1834, pouco se fez pela educação, salvo o projeto de lei de 1827, que determinava a criação de escolas de primeiras letras em todo o país. O Ato Adicional de 1834 determinou a descentralização da educação de $1^{\circ}$ e $2^{\circ}$ graus e determinou a garantia da instrução primária gratuita como dever das províncias. Contudo, como atesta o parlamentar Visconde de Uruguai, a educação não era o forte do parlamento e o mesmo se pode dizer do governo central que investia apenas $1 \%$ da renda do império na educação e somente no ensino superior, deixando à míngua a educação popular. 
Está claro que, para a classe dominante, o mais importante era uma escola superior destinada a preparar as elites políticas e quadros profissionais de nível superior em estreita consonância com a ideologia política e social do Estado, de modo a garantir a construção da ordem, a estabilidade das instituições monárquicas e a preservação do regime oligárquico.

O relatório de Gonçalves Dias ${ }^{5}$ também confirma que a realidade da educação do período era muito ruim e muito abaixo do esperado, salvo algumas exceções. A estrutura da instrução nas províncias era precária, com escassez orçamentária, baixa frequência escolar, má administração, falta de mão-de-obra qualificada, baixos salários. Os negros e índios não recebiam qualquer tipo de instrução, a não ser formação religiosa para conhecerem os mandamentos de Deus e abandonarem a devassidão de costumes - "nada há de esperar das assembleias provinciais", atesta o relator.

\section{A SOCIEDADE E A EDUCAÇÃO BRASILEIRA NO DECLINAR DO IMPÉRIO E INÍCIO DA REPÚBLICA}

Destaca-se, agora, o período em que se dá a construção da República no Brasil, no final do século XIX e início do século XX, período que também demarca o fim oficial da escravidão e da monarquia; início, portanto, do trabalho assalariado, bem como de mudanças no Estado e na legislação. Nesse contexto, as classes dominantes passam por várias formas de reorganização; vários interesses regionais entram em cena, bem como múltiplos interesses e pressões para por fim à escravidão. $\mathrm{O}$ cenário externo também é bastante agitado, tanto na América como na Europa e África; esse cenário externo influia na conjuntura interna, fazendo perceber que o escravismo não era mais admissível. São Paulo é uma das primeiras capitais brasileiras a dar início à migração da economia para o modo capitalista.

A República, de acordo com Neves (2003), não é um fato repentino; pelo contrário, é resultado de um desenrolar de fatos de longa duração. Ou seja, a "quartelada" não surgiu do nada; nesse sentido, foi ponto de chegada de um processo. Contudo, mesmo esperada com muita expectativa, de fato, a consolidação da República não conseguiu resolver as várias contradições da nação, dentre elas, as da educação. $O$ fato é que a República não colocou o Brasil na ordem dos países civilizados, desenvolvidos, que trilham em direção ao progresso. Num panorama internacional de grandes progressos econômicos, culturais, científicos, o Brasil se apresentava nas exposições internacionais com suas pedras e madeiras preciosas, peles de animais selvagens, produtos agrícolas e arte plumária.

O Brasil republicano continuava inscrito, no cenário mundial, como país dependente e periférico, apesar da grande riqueza que possuía; contudo, não continuava mais exclusivamente na área de influência inglesa; outros investimentos e interesses internacionais aqui aportaram, notadamente, os norte-americanos. Os desvãos da ordem e do progresso no Brasil escondiam a pobreza, a miséria, o analfabetismo e outras mazelas sociais. Os velhos problemas da nação brasileira desfilavam campo afora na nova ordem republicana. A velha ordem excludente e hierarquizada se mantinha - agora, sob novas formas. Ou seja: a nova ordem não impedia que se tornassem mais profundos os contrastes sociais.

Sales (1986) destaca que um setor da classe dominante - organizado no Partido Republicano Paulista - traçou todo um projeto em vista da construção de uma sociedade civilizada, na qual os homens eram moldados para o trabalho e para o exercício da política. Entretanto, o negro continuou a não ter lugar também na República, na medida em que o trabalho do escravo ia sendo substituído pelo trabalhador livre e se impondo como definidor das relações de produção. Para isso, foi constituído um aparato jurídico- 
institucional, que assegurava o contrato de compra e venda da força de trabalho e também se desenvolveu todo um arcabouço ideológico capaz de convencer os homens da sua igualdade social - não somente a igualdade, como também, a liberdade e a fraternidade.

Também se disseminou a ideia da ciência como condição para o progresso e civilização. Progresso é sinônimo de desenvolvimento econômico e ampliação da participação política. Por meio do esforço individual, do trabalho, chega-se à riqueza. Ou seja: os homens trabalhando se enriquecem e enriquecem a nação. Em tal contexto, a educação se torna fundamental, pois ela é a responsável pela formação profissional e intelectual do povo, tornando-o apto para sua inserção no mercado de trabalho e, desse modo, no exercício da cidadania. A educação é a celebração do progresso.

A educação como celebração do progresso é tema analisado por Júnior (2001). O autor destaca que a educação, nas vitrines do Brasil, no interior das exposições internacionais, era apresentada como signo de civilização, de progresso, de sociedade moderna. A educação era identificada como elemento constitutivo da sociedade moderna; alicerce da vida civilizada, produtora do progresso. Deve-se, contudo, destacar que o Brasil das exposições era carregado de ambiguidades e camuflava o Brasil real, marcado por profundas desigualdades.

Contudo, mesmo existindo grande expectativa em relação ao papel a ser desenvolvido pela educação no período republicano, Nagle (1989) descreve que a mesma, tanto do ponto de vista quantitativo, como qualitativo, não consegue realizar parte das aspirações a que se propõe realizar e, mesmo havendo toda uma reestruturação na primeira Constituinte republicana ${ }^{6}$, logo perdeu a força e ímpeto inicial.

Do ponto de vista social, avançava o processo de imigração. Os imigrantes passam a assumir o papel de abastecer o mercado com mão-de-obra para a agricultura. Parte deles vai, mais tarde, formar a classe operária brasileira, considerada baderneira, anarquista por sua forma de atuação ${ }^{7}$. Nesse contexto, a educação vai tratar de construir um novo cidadão; logo, faz-se nova leitura do papel da escola. O operário precisa ser alfabetizado, e a escola torna-se ainda mais necessária, inclusive do ponto de vista político, pois, para exercer o direito do voto ${ }^{8}$ o indivíduo precisava ser alfabetizado.

A educação também assume sinais de contradição uma vez que o analfabeto, de modo geral, trabalha sem reclamar, enquanto os alfabetizados tornam insolentes e podem até ler o jornal do sindicato. Logo, em tal situação histórica, a educação precisava ser ideologizada, amoldada aos interesses dos proprietários. Como não houve base material que a sustentasse, a escola, como signo da instauração da nova ordem e arma para efetuar o progresso, logo se transformou em frustração. A constatação a que se chegou, conforme Carvalho (1989), é a de que a República relegou ao abandono milhões de analfabetos de letras e de ofícios. Esse número de excluídos se apresentava como antítese à realização do progresso.

\section{DÉCADA DE 1920 AOS NOSSOS DIAS}

A década de 1920 foi marcada por uma grande efervescência e profundas transformações ${ }^{9}$. O Brasil encontrava-se mergulhado numa profunda crise econômica. Nesse contexto, estavam a Semana de Arte Moderna (1922); a criação do Partido Comunista, do movimento tenentista; do centro Dom Vidal; comemoração do centenário da independência e a sucessão presidencial de 1922. Esses fatos marcaram política e culturalmente a primeira república.

No plano econômico, a crise de 1929 gerou sérios problemas à economia brasileira, tais como, a alta da inflação e a crise fiscal sem precedentes. Por outro lado, a economia brasileira tornou-se mais complexa a partir da diversificação da agricultura, de um maior 
desenvolvimento das atividades industriais, da expansão de empresas já existentes e do surgimento de novos estabelecimentos ligados à indústria de base. Houve uma ampliação dos setores urbanos com o crescimento das camadas médias da classe trabalhadora e a diversificação de interesses no interior das próprias elites econômicas.

Nesse contexto, a escola ${ }^{10}$ novamente foi evocada como arma para superação dos entraves que impediam o progresso; porém, era uma arma perigosa que precisava ser redefinida como instrumento de dominação. Forjava-se, então, um projeto político autoritário: educar era obra de moldagem de um povo - matéria bruta a ser trabalhada, em consonância com os anseios de ordem e progresso de um grupo que se autoinvestia como elite e com autoridade para promovê-lo.

A vadiagem, as greves geravam preocupações; nessas condições, a educação teve um papel fundamental, não tanto no sentido de disseminar o perigo das letras, mas no sentido do dever domiciliário. Também não bastava ensinar, era preciso saber ensinar. Nesse caso, os métodos passaram a ter importância decisiva e a reforma de Caetano Campos cuidou de tudo muito detalhadamente, baseada no primado da visibilidade. A reforma de Caetano de Campos trazia a concepção de que a cidadania plena só era facultada por um ensino por inteiro, completo, de base científica, porém, sua generalização ficava postergada para um futuro remoto na dependência de morosas providências pedagógicas.

Em 1926, em pleno estado de sítio, ocorreu nova revisão constitucional, e a educação foi tema de tal revisão. Na Velha República, já estava claro quem eram os responsáveis pela educação escolar entre as instâncias da federação. $\mathrm{O}$ ensino fundamental deveria ser assumido por todos os estados da Federação, portanto, não era da competência do governo federal.

Na Revisão Constitucional de 1925/26, Cury (1996) enfatiza a intervenção de organizações civis preocupadas com a correlação ensino/nacionalidade/progresso, dentre elas a atuação da Associação Brasileira de Educação - ABE, Igreja Católica, ligas nacionalistas e das próprias Conferências Nacionais de educação. Um dos temas, na discussão da Reforma, foi o papel do Estado no seu dever de oferecer instrução para todos. Para o autor, a Revisão Constitucional revelou dois pontos importantes: o primeiro foi a elucidação do papel da União quanto à instrução básica; o segundo, a concepção da educação como direito social.

Nesse contexto histórico, deve-se destacar também a forte intervenção dos Pioneiros da Educação Nova e a I Conferência Brasileira de Educação realizada em1927 na cidade de Curitiba ${ }^{11}$. O movimento Escola Nova organizou-se em torno de alguns temas de relevância, tais como: a escola deveria ser pública, universal, laica e gratuita; deveria ser para todos, e todos deveriam receber o mesmo tipo de educação. Caberia ao setor público, e não ao particular, a realização de tal empreendimento. Também propunha uma revolução nos métodos pedagógicos, acabando com o autoritarismo educacional.

O movimento católico também fortaleceu-se muito no Brasil, no início do século XX, principalmente nos anos de 1930, a partir da atuação de Francisco Campos, ligado ao movimento católico, e que procurou fazer a aproximação da Igreja com o governo Vargas; no entanto, o movimento católico manifestou-se hostil e contra tal pacto. A Igreja via a revolução como perigosa, com ideias liberais e positivistas. No Rio, o Cardeal Leme, na inauguração do Corcovado, diz à multidão: "ou o Estado reconhece o Deus do povo, ou povo não reconhece o Estado".

Além da Igreja, as forças armadas também viam a educação como caminho para a construção do projeto nacional de longo alcance. É desse período o projeto fascista de Francisco Campos, que visava a um maior controle da educação pelo Estado, o que não 
agradou à Igreja, e a solução foi sua saída do Ministério e a entrada de Gustavo Capanema. Capanema, à frente do Ministério da Educação, empenhou-se em disseminar a crença de poder moldar a sociedade a partir da formação das mentes e da abertura de novos espaços de mobilidade social e participação política.

Capanema, conforme Schwartzman et al. (2000) defendia a ideia de que optar por esta ou aquela forma de organização, controle ou orientação pedagógica significaria levar a sociedade para rumos totalmente distintos - de salvação ou tragédia nacional. Na construção e consolidação do Estado Nacional, a educação é vista como um espaço que deve ser utilizado para se construir a ideologia do Estado Novo, cuja tarefa é a de "abrasileirar" o Brasil. Em 1936, Capanema distribui extenso e minucioso questionário ${ }^{12}$, buscando colaboração de professores, estudantes, jornalistas, escritores, cientistas, sacerdotes e políticos para a elaboração de um Plano Nacional de Educação. Um dos frutos desse plano foi a reforma do ensino secundário de 1940/42.

Mudanças e reformas mais acentuadas no campo educacional se fariam sentir novamente a partir da década de 1960, com a queda do regime democrático e do período dos governos de Juscelino Kubischequi e João Goulart e a ascensão do regime militar cravados no Golpe Militar de $1964^{13}$. Os militares, ao lado de seus aliados civis, tomaram o poder em março de 1964 e implantaram uma ditadura que durou muito além do previsto. Para se manter, o regime recorreu à violência, à censura e à espionagem. Nesse processo conturbado e contraditório, muitos melhoraram de vida com o chamado milagre econômico; por outro lado, muitos outros se tornaram ainda mais pobres do que eram ${ }^{14}$.

Houve resistências por parte de políticos, religiosos, estudantes, artistas e intelectuais. Contudo, eram pequenos grupos, na maioria, formados por jovens que, desejando implantar o socialismo no país, pegaram em armas e atacaram a ditadura, a exemplo dos militantes da guerrilha do Araguaia ${ }^{15}$.

A transição de volta à democracia, como a própria duração do regime militar no Brasil, foi uma das mais longas na América Latina. Ao final dos anos de 1970, os operários também entraram em cena, logo seguidos por trabalhadores rurais, e o Brasil lentamente está construindo uma democracia em bases mais sólidas.

Durante o regime militar, ocorreu a revisão da primeira Lei de Diretrizes e Bases da Educação, criada em 1961, com a versão de 1971 que patrocinou a reformulação de vários aspectos da estrutura organizacional da educação brasileira, com ênfase à reforma da educação secundária que profissionalizou esse nível de ensino. Nova organização da estrutura educacional brasileira ocorreu em 1996, com o lançamento da segunda LDBEN (Lei 9394/1996), bem como, com a promulgação de vários decretos, principalmente nos governos de Fernando Henrique Cardoso e Luiz Inácio Lula da Silva ${ }^{16}$. Aconteceram discussões de maior envergadura acerca da educação como direito social a ser desenvolvido e ofertado de forma pública, gratuíta e de qualidade, ou seja, discussões acerca do papel da educação no desenvolvimento do pensamento científico e social e da nação brasileira. Além do processo de elaboração da atual LDBEN, outros momentos de intensos debates acerca do papel social da educação se deram durante o processo de discussão para a elaboração das metas do Plano Nacional de Educação de 2001 e 2010.

Durante o governo Fernando Henrique Cardoso, foi discutido e aprovado o primeiro Plano Nacional de Educação (PNE) pela Lei 10.172/01, a ser implementado entre os anos de 2001-2010. Contudo, o item de maior impacto, ou seja, o investimento de 7\% do Produto Interno Bruto (PIB) em Educação foi vetado por FHC e sem recursos públicos a maior parte das metas estipuladas tornaram-se quimeras. Para o processo de elaboração do segundo plano de educação, ocorreu todo um movimento de discussão nas bases que culminou com a realização da Conferência Nacional de Educação (CONAE), realizada 
entre os dias 28 de março a $1^{\circ}$ de abril de 2010. Dessa conferência, tiraram-se diretrizes para o PNE 2011/2020. O documento da conferência organizou prioridades e propôs metas a serem alcançadas nos dez anos seguintes; porém, muitas delas não foram incorporadas ao Projeto de Lei 8035/10 em discussão no Congresso Nacional, sendo a de maior relevância a que previa a elevação de recursos em educação, passando de 4,7\% em 2008 para $7 \%$ em 2011 e alcançando $10 \%$ em 2014.

Em arremate, pode-se afirmar que, mesmo existindo nova mentalidade em formação e com projetos numa perspectiva emancipatória e, quiçá socialista, percebe-se que o Brasil, assim como em outras nações ditas em desenvolvimento, ainda padece da carência de recursos suficientes para alavancar o desenvolvimento global da nação. Inclusive com aporte de recursos suficientes para garantir educação de qualidade em todos os níveis e para todas as pessoas.

É bem verdade que o irracional, o mítico, o folclórico, o senso comum continuam tendo importância e lugar na vida cotidiana das pessoas; no entanto, o pensamento racional, a ciência e a técnica vão se firmando cada vez mais como espaço explicativo da realidade. Contudo, o Brasil, desde sua descoberta até nossos dias, praticou a lógica da exclusão, do elitismo, do pouco caso com as questões sociais, dentre elas, a educação. Nesse ínterim, surge um questionamento inevitável: será que o Brasil continuará a ser somente a nação do futuro?

\section{REFERÊNCIAS}

ALMEIDA José Ricardo Pires de - História da Instrução pública no Brasil (1500-1889) história e legislação. Brasília: INEP-PUC/SP, 1989.

AZEVEDO, Fernando de - Princípios de Sociologia. $8^{\text {a }}$ ed. São Paulo: Edições Melhoramentos, 1958.

BATALHA, Cláudio H. M. - Formação da classe operária e projetos de identidade coletiva. In: FERREIRA, Jorge Delgado e NEVES, Lucília de Almeida (Orgs.) - O Brasil republicano - o tempo do liberalismo excludente - da proclamação da República à revolução de 1930. Rio de Janeiro: Civilização brasileira, 2003.

BETHEL, Leslie. - História da América Latina: da independência até 1870. V. III. São Paulo, co-edição Imprensa Oficial/EDUSP/FUNAG, 2001. Tradução Maria Clara Cescato. 2001.

BRASIL. Lei N. 10.172 de 09 de Janeiro de 2001. Disponível em: <http://www.planalto.gov.br/ccivil_03/leis/leis_2001/110172.htm>. Acesso em 05/09/2011. CARVALHO, José Murilo de - A construção da Ordem. Teatro das Sombras. Rio de Janeiro: Editora UFRJ, 1996.

CARVALHO, Marta M. Chagas de - A escola e a república. Coleção Tudo é História, n. 127. São Paulo: brasiliense, 1989.

CHIZZOTI, Antônio - A Constituinte de 1823 e a educação. In: Fávero, Osmar (org.) - A educação nas Constituintes brasileiras: 1823-1988. Campinas: Autores Associados, 1996.

COAN, Marival - A sociologia no ensino médio, o material didático e a categoria trabalho. 2006, 356 f.. Dissertação (Mestrado em Educação PPGE/CED/UFSC), 2006. Disponível em: 〈http://www.ppgeufsc.com.br/ferramentas/ferramentas/tese_di/5.pdf $>$. 
COSTA, Cristina - Sociologia: Introdução à Ciência da Sociedade. São Paulo: Moderna 2000.

COSTA, Maria José Franco Ferreira da et al (Orgs) - I Conferência Brasileira de educação - Curitiba, 1927. Brasília: MEC-SEDIAE/INEP-ÍPARDES, 1997.

CURY, Carlos Jamil - A educação e a primeira Constituinte republicana. In: Fávero, Osmar (org.) - A educação nas Constituintes brasileiras: 1823-1988. Campinas: Autores Associados, 1996. . - A educação na revisão constitucional de 1926. In: Fávero, Osmar (org.) - A educação nas Constituintes brasileiras: 1823-1988. Campinas: Autores Associados, 1996. FERNANDES, Florestan - A Sociologia no Brasil. 2a ed. Petrópolis-RJ: Vozes, 1980. - Mudanças sociais no Brasil. Aspectos do desenvolvimento da sociedade brasileira. São Paulo: difusão européia do livro, 1974.

FERREIRA, Gabriela Nunes - Centralização e descentralização no império o debate entre Tavares Bastos e Visconde de Uruguai. São Paulo: Co-edição departamento de Ciência Política da USP e editora 34, 1999.

FERREIRA, Marieta de Moraes e PINTO, Suzana Conde Sá - A crise de 1920 e a Revolução de 1930. In: FERREIRA, Jorge Delgado e NEVES, Lucília de Almeida (Orgs.) - O Brasil republicano - o tempo do liberalismo excludente - da proclamação da República à revolução de 1930. Rio de Janeiro: Civilização brasileira, 2003.

FONSECA, Marcus Vinicius - A educação dos negros: uma nova face do processo de abolição da escravatura no Brasil. Bragança Paulista: editora da Universidade de São Francisco/CDAPH, 2002.

FRAGOSO, João e FLORENTINO Manolo - O arcaísmo como projeto - mercado atlântico, sociedade agrária e elite mercantil em uma economia colonial tardia - Rio de Janeiro, c. 1790 - c. 1840. Rio de Janeiro: Civilização Brasileira, 2001.

FURTADO, Celso - Teoria e política do desenvolvimento econômico. São Paulo: Nova Cultural, 1986.

IANNI, O. A sociologia numa época de globalismo, in: FERREIRA L.(org.). A sociologia no horizonte do século XXI. São Paulo: Boitempo, 1997.

JINKINGS, Nise - As particularidades e os desafios do ensino de Sociologia nas escolas. In: DIAS, M. de F. S; SOUZA, S.C. de; SEARA, I.C. (Org.) - Formação de Professores Experiências e Reflexões. Florianópolis: Letras Contemporâneas, 2006.

JÚNIOR Moisés Kuhlmann - As grandes festas didáticas: a educação brasileira e as exposições internacionais (1862- 1922). Bragança Paulista: editora da Universidade São Francisco-CDAPH, 2001.

MALHEIRO, Agostinho Marques Perdigão - A escravidão no Brasil - ensaio históricojuridico-social. Rio de Janeiro: Typografia Nacional, 1867.

MORAIS, Tais de. SILVA, Eumano - Operação Araguaia: os arquivos secretos da guerrilha. São Paulo: Geração Editorial, 2005.

NAGLE, Jorge - A educação na Primeira República. In: HOLANDA, Sérgio Buarque de História Geral da Civilização brasileira - III. O Brasil republicano - 2. Sociedade e Instituições (1889-1930). São Paulo: Difel, 989. 
NEVES, Lúcia. M. W. ; PRONKO, Marcela - O mercado do conhecimento e o conhecimento pra o mercado: da formação pra o trabalho complexo no Brasil contemporâneo. $1^{\text {a }}$ ed. Rio de Janeiro: EPSJV, 2008. v. 1. 204 p.

NEVES, Margarida de Souza - Os cenários da República. O Brasil na virada do século XIX para o século XX. In: FERREIRA, Jorge Delgado e NEVES, Lucília de Almeida (Orgs.) - O Brasil republicano - o tempo do liberalismo excludente - da proclamação da República à revolução de 1930. Rio de Janeiro: Civilização brasileira, 2003.

OLIVEIRA, Cecília Helena de Salles - Tramas políticas, redes de negócio. In: JANCSO, István (org.) - Brasil: formação do estado e da Nação. São Paulo-Ijuí/RS: Co-edição PAPESP/Editora Hucitec/Editora Unijui, 2003.

PIMENTA, João Paulo G. - Estado e nação no fim dos impérios ibéricos no Prata (18081828). São Paulo: Hucitec/PAPESP, 2002.

PRADO, Luiz Carlos Delorme e EARP, Fábio Sá - O milagre brasileiro: crescimento acelerado, integração internacional e concentração de renda (1967-1973). In:

FERREIRA, Jorge e Delgado, NEVES, Lucília de Almeida (orgs) - O Brasil republicano $O$ tempo da ditadura - regime militar e movimentos sociais em fins do século $X X$, volume 4. Rio de Janeiro: Civilização Brasileira, 2003.

RODRIGUES, José Honório - A assembléia Constituinte de 1823. Petrópolis/RJ: Editora Vozes, 1974.

ROWLAND, Robert - Patriotismo, povo e ódio aos portugueses: notas sobre a construção da identidade nacional no Brasil independente. In: JANCSO, István (org.) - Brasil: formação do estado e da Nação. São Paulo-Ijuí/RS: Co-edição PAPESP/Editora Hucitec/Editora Unijui, 2003.

SALLES, Iraci Galvão - Trabalho, progresso e a sociedade civilizada. São Paulo: Hucitec, 1986.

SHIAVINATTO, Iara Lis - Imagens do Brasil: entre a natureza e a história. In: JANCSO, István (org.) - Brasil: formação do estado e da Nação. São Paulo-Ijuí/RS: Co-edição PAPESP/Editora Hucitec/Editora Unijui, 2003.

SUCUPIRA, Newton - $O$ ato adicional de 1834 e a descentralização da educação. In: FÁVERO, Osmar (org.) - A educação nas Constituintes brasileiras: 1823-1988. Campinas: Autores Associados, 1996.

SCHWARTZMAN, Simon et all - Tempos de Capanema. São Paulo: Paz e Terra e editora da FGV, 2000.

VIEIRA PINTO, Álvaro - A Sociologia dos Países Subdesenvolvidos. Rio de Janeiro: Contraponto, 2008 - ISBN: 8585910992.

VIOTTI, Emília da Costa - Da Monarquia à República: momentos decisivos. São Paulo: Editora da UNESP, 1998.

VON MARTIUS, Karl Philipp - Como se deve escrever a história do Brasil. Rio de Janeiro: Revista trimestral de História e Geographia. n. 24, janeiro de 1845.

TAVARES, Maria da Conceição - Da substituição de importações ao capitalismo financeiro. Rio de Janeiro: Zahar, 1972.

TEIXEIRA, Anísio - O manifesto dos Pioneiros da educação nova. Brasília: Revista brasileira de estudos pedagógicos, v. 65, n.150, maio/agosto. 1984 p. 407-425. 


\section{Notas:}

${ }^{1}$ Licenciado em Filosofia, com habilitação em Sociologia e Psicologia, Bacharel em Teologia, especialista (lato sensu) em Metodologia do Ensino Superior, e Educação a Distância; Mestre em Educação (PPGE/UFSC) e doutor em Educação pelo PPGE/UFSC. Participa do Grupo de Estudos sobre Política Educacional e Trabalho (GEPETO) e do grupo de pesquisa em educação do IFSC, onde é professor efetivo. Email: marival@ifsc.edu.br.

${ }^{2}$ Documento mestre que serve de orientação para a educação da Ordem dos Jesuítas. Ver P. Leonel Franca. Disponível

http://www.histedbr.fae.unicamp.br/navegando/fontes_escritas/1_Jesuitico/ratio\%20studiorum.htm. Bem como, O Ratio Studiorium e a missão no Brasil de Karen Fernanda da Silva Bortoloti. http://www.anpuh.uepg.br/historia-hoje/vol1n2/ratio.htm.

${ }^{3} \mathrm{O}$ debate acerca da centralização/descentralização da administração do império pode ser melhor acompanhado em Ferreira (1999). A autora situa o debate travado entre Tavares Bastos e Visconde de Uruguai. Os autores se encontram em polos opostos do debate acerca da centralização e descentralização política e administrativa, num momento de questionamento da ordenação institucional vigente.

${ }^{4}$ A este respeito, ler o apêndice n. 15 da obra supracitada de autoria do Dr. Caetano Alberto Soares - No melhoramento da sorte dos escravos no Brasil. Poderá ser abolida entre nós a escravidão? Porque modo?

5 Trata-se de um documento que analisa a instrução pública nas diversas províncias do norte. O trabalho foi encomendado pelo imperador Pedro II, em 1849, cujo objetivo era diagnosticar a situação da instrução pública no Norte do Brasil; o trabalho final foi apresentado em 1852. A respeito desse relatório, ler Almeida (1989).

${ }^{6}$ Há afirmação de uma rede oficial dividida entre a União e Unidades Federadas, ao lado de uma liberdade para abertura de escolas de mercado; a escola pública é laica; omissão quanto à obrigatoriedade/gratuidade da instrução pública primária. Não se pode dizer que a Constituinte tenha ignorado a educação, porém, percebese um liberalismo excludente e pouco democrático agindo por dentro da Assembleia Constituinte. Ver Cury (1996) A educação e a primeira Constituinte republicana.

${ }^{7}$ Ver Batalha (2003). Formação da classe operária e projetos de identidade coletiva.

${ }^{8}$ Cury (1996) explicita que o Decreto $\mathrm{n}^{\circ} 6$ extinguiu o voto censitário e impôs o saber ler e escrever como condição do acesso à participação eleitoral. A instrução pública passa ser obrigação das unidades federadas.

${ }^{9}$ Outros elementos do contexto podem ser obtidos em Ferreira e Pinto (2003) A crise de 1920 e a Revolução de 1930, bem como, em Batalha (2003) Formação da classe operária e projetos de identidade coletiva.

${ }^{10}$ É desse período a fundação da associação brasileira de educação - ABE - em 1924, não como obra dos educadores e sim de médicos, engenheiros, advogados, entre outros, preocupados com a questão da educação. A $\mathrm{ABE}$ vê a educação como uma perspectiva messiânica, ela regenerará os degenerados. Nesse momento, entra na educação brasileira o movimento da escola nova que passa a olhar a escola a partir de dentro, de seus métodos, conteúdos, proposta.

${ }^{11}$ Acerca do manifesto dos Pioneiros, ver Teixeira (1984) e da I Conferência de educação, ver Costa et al. (1997).

${ }^{12} \mathrm{O}$ questionário composto de 213 perguntas inquiriam sobre todos os aspectos possíveis de ensino, e as respostas refletiam as várias concepções, interesses acerca da educação. Destaque para as ideias dos representantes da escola nova e da igreja que exprimiram de modo mais articulado suas concepções de educação.

${ }^{13}$ Outras informaç̃es acerca do contexto podem ser obtidas em Ferreira e Delgado (orgs). De modo especial, no texto de Prado, e Earp (2003): O milagre brasileiro: crescimento acelerado, integração internacional e concentração de renda (1967-1973), bem como, em Álvaro Vieira Pinto (2008) e Florestan Fernandes, de modo especial: Mudanças sociais no Brasi (1974).

${ }^{14}$ Houve um grande crescimento econômico, porém, não houve justiça social, distribuição de renda. Segundo os economistas C. Furtado (1986) e Maria C. Tavares (1972), a má distribuição de renda era uma característica estrutural do sistema, sem o qual o dinamismo econômico desse período não seria possível. $\mathrm{O}$ desenvolvimento econômico - momentaneamente atingido, não superou os problemas estruturais de nação subdesenvolvida.

${ }^{15}$ Há bibliografia vasta acerca de tal episódio. Sugere-se ler MORAIS: Operação Araguaia: os arquivos secretos da guerrilha.

${ }^{16}$ A este respeito ver os Decretos 2028/1996; 2208/1997; 5154/2004, bem como a obra de Neves e Pronko (2008).

Recebido em: $\quad 17 / 06 / 10$

Aprovado em: $\quad 25 / 01 / 11$ 